\title{
Analysis of English Learning Difficulty of Students in Elementary School
}

\author{
Ni Made Dita Sintadewi ${ }^{1}$, Ni Putu Juni Artini ${ }^{2}$, Irwan Febryan ${ }^{3}$ \\ ${ }^{1}$ Prodi Pendidikan Bahasa Inggris, Universitas Triatma Mulya, Indonesia \\ 23 Prodi Pendidikan Guru Sekolah Dasar, Universitas Triatma Mulya, Indonesia
}

\author{
A R T I C L E I N F O \\ Article history: Received 2 \\ Juni 2020 Received in \\ revised form 12 Juli 2020 \\ Accepted 10 Agustus 2020 \\ Available online 28 Agustus \\ 2020 \\ Kata Kunci: \\ Kesulitan belajar, Bahasa \\ Inggris. \\ Keywords: \\ Learning difficulties, English
}

\begin{abstract}
A B S T R A K
Rendahnya hasil belajar siswa disebabkan oleh siswa beranggapan bahwa Bahasa Inggris pelajaran yang sulit dan membosankan sehingga siswa kesulitan dalam memahaminya. Tujuan dari penelitian ini adalah untuk menganalisis jenis kesulitan belajar Bahasa Inggris yang dialami siswa, faktor yang mempengaruhi kesulitan belajar, dan mengungkapkan upaya yang dapat dilakukan untuk mengatasi kesulitan belajar Bahasa Inggris di kelas V Sekolah Dasar. Metode penelitian ini menggunakan deskriptif kualitatif. Subyek penelitian yaitu siswa kelas V sebanyak 22 orang dan guru kelas V. Prosedur pengumpulan data yang digunakan adalah wawancara, angket dan dokumentasi. Analisis data menggunakan pendekatan kualitatif. Hasil penelitian ini adalah ada 16 siswa mengalami kesulitan belajar Bahasa inggris, dan juga tidak paham ketika guru menyampaikan materi Bahasa Inggris. Faktor-faktor yang menyebabkan kesulitan belajar Bahasa Inggris siswa kelas $\mathrm{V}$ adalah faktor internal yaitu siswa masih kurang termotivasi dan kurang berminat dalam mengikuti pelajaran Bahasa Inggris sedangkan faktor eksternalnya adalah guru kurang menggunakan alat peraga dan metode yang digunakan kurang
\end{abstract} bervariatif dan tidak inovatif. Berdasarkan hasil tersebut diatas maka dapat disimpulkan bahwa siswa kelas V SD masih berkesulitan dalam mempelajari pelajaran Bahasa Inggris. Sehingga dapat disimpulkan bahwa kesulian belajar siswa akan berdampak pada hasil belajar yang rendah.

\section{A B S T R A C T}

The low student learning outcomes are caused by students' thought that English is a difficult and boring subject so that students have difficulties understanding it. The purpose of this study is to analyze the types of learning difficulties experienced by students, the factors that affect learning difficulties, and to find out the efforts to overcome the difficulties of learning English in grade V of Elementary School. This research method uses descriptive qualitative. The research subjects were 22 grade $\mathrm{V}$ students and grade $\mathrm{V}$ teachers. The data collection procedures used were interviews, questionnaires, and documentation. Data analysis used is a qualitative approach. The results of this study were 16 students experienced difficulty learning English, and also did not understand when the teacher delivered English materials. The factors that cause difficulty in learning English for grade $\mathrm{V}$ students are internal factors, including students are still less motivated and less interested in taking English lessons, while the external factor is that the teacher does not use teaching aids and the methods used are less varied and not innovative. Based on the above results, it is showed that grade V Elementary School students still have difficulty learning English lessons. Therefore, it can be concluded that students' learning concerns will have an impact on low learning outcomes.

\section{Introduction}

Education is needed to improve the quality of human resources. Education will provide opportunities for humans to advance and get a good life. education is a structured arrangement in order to mature someone (Miskawati, 2019; Wirasasmita \& Hendriawan, 2020). Education will make a person become a religious person, have a noble character, are intelligent and have skills (Sujana, 2019). In this regard, the learning process must be carried out as much as possible so as to produce quality human resources. Efforts to improve the quality of education require hard work from various parties, ranging from education personnel, parents, students, society and the government to achieve the final goal, namely

Copyright (C) Universitas Pendidikan Ganesha. All rights reserved.

Corresponding author.

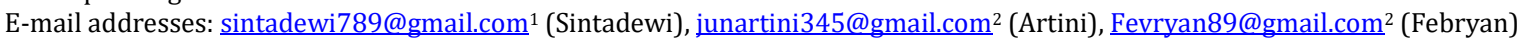


quality human resources, so that students need to be prepared from an early age. So that educational goals can be achieved optimally.

One of the educational problems faced by the Indonesian nation is the low quality of education (Suryana, 2017; Widodo, 2015). Various efforts have been made to improve the quality of national education, including through various trainings, increasing teacher qualifications, refining curricula, procuring books and learning tools, improving other facilities and infrastructure, and improving school management. The difficulties that are often faced by elementary school students in facing English learning are difficulties in understanding text and in understanding language skills (Basri, 2018; Ratminingsih, 2017). Even though students who do not like English lessons can experience low English learning due to various problems. One of the problems in learning English is the opinion of most students that English is a difficult and boring subject, so that many students do not like English lessons and even make English as one of the lessons that have difficulty understanding the material presented and have an impact on its low English learning achievement. (Slameto, 2010) states that students with high levels of anxiety do not perform as well as students with low levels of anxiety.

This problem was also found in one elementary school. Based on the results of observations from the English teacher at SDN 4 Pendem District Negara, that English lessons on students' ability to learn English are still low. Students 'vocabulary mastery is still lacking so that students experience difficulties in following lessons, while vocabulary mastery itself affects students' ability to read, write, listen, and speak as well as pronunciation. Some say that learning difficulties in students are caused by the low willingness of students to learn English, students find it difficult to remember the meaning of words in English, there are also those who say the difficulty of these students is because the teacher who teaches does not specialize in the field of English, learning English is very boring, and short hours of English lessons do not optimize learning English in schools. According to the results of the interview, the learning outcomes in the form of passing scores for daily tests and general tests of English were still not optimal. It is known from student learning outcomes that are still below the Minimum Completeness Criteria that have been set by the school.

Learning activities in schools are part of educational activities that will lead students to a better state. In the learning process, it is necessary to have a good motivator and facilitator, namely the presence of a teacher in front of the class. The teacher is one component in the teaching and learning process. The teaching and learning process is a series of interactions between teachers and students in order to achieve learning objectives (Makmun, 2001; Susanto, 2013). The ability of students to understand learning concepts is different from one another. This can make them have differences of opinion in solving a problem. The more mastered a concept in learning, it is expected that solving a problem will be easier, and learning outcomes will be better (Farnika, Ikhsan, \& Sofyan, 2015; Wahyudi \& Indri, 2017). Uno (2007) states that learning can be defined as a process of interaction between learning participants and teachers in a learning environment to achieve certain learning goals. In the learning process in class, a teacher often comes across students who have learning difficulties. Sugihartono (2007) defines learning difficulties as a symptom that appears to students which are characterized by low learning outcomes or under predetermined norms. Learning outcomes of students who have learning difficulties, learning outcomes are lower when compared to their peers. Students who score below the Minimum Completeness Criteria can also be said to have learning difficulties (Izaak, Esomar, \& Sopacua, 2016). Learning difficulties are often found in English (Kurniawati, 2019; Lubis, 2018).

English is one of the languages spoken internationally. So that English is used as an important basic competency for people who want to be insightful and knowledgeable. As a part of culture, language plays an important role in business talks between nations. Therefore, English is one of the important subjects taught in schools. So, it is hoped that graduates who master English well will provide the widest possible room for them to become part of the global community of the world community. Therefore, education in elementary schools should introduce English to students from an early age. Within the framework of cross culture (cross culture), English, which is used as an international language, then becomes unique because each nation has a different cultural background, which of course affects dialects, grammar pronunciation and different behavior. English lessons have four skills that must be mastered, namely listening, speaking, reading and writing (Astuti, 2017; Miranti, 2015). Language has a central role in the intellectual, social, and emotional development of students and is a supporter of success in studying all fields of study (Mansyur, 2016). Learning English is different from learning other sciences, language is a communication tool in dealing with other people. It is not enough just to know the theory of English grammar, both structure and vocabulary, but practice speaking with high frequency will make a person more accustomed to pronouncing English sentences.

Based on the explanation above, the research objectives were formulated, namely to analyze the types of English learning difficulties experienced by students, the factors that affect learning difficulties, 
and to reveal the efforts that could be made to overcome the difficulties of learning English in grade $\mathrm{V}$ Elementary School. This research is expected to be able to solve the problems faced by students in English by revealing the efforts that can be made to overcome the problems.

\section{Method}

This study used a qualitative approach with the Miles and Huberman model. This approach was chosen because this study aims to analyze the learning difficulties of students by describing the learning objectives that have been determined.

The subjects in this study were the homeroom teacher and the fifth-grade students of SD Negeri 4 Pendem, totaling 22 students. The sampling technique used in this study was purposive. Key informants or initial informants were selected purposively. In this study, who acted as the initial informant was the homeroom teacher of SD Negeri 4 Pendem. The next informant was the fifth-grade student of SD Negeri 4 Pendem who was determined by the snowball sampling technique. For research purposes, five students were selected with the category of low ability students. This categorization is based on student learning outcomes. In addition, the selection of research subjects was also based on suggestions from the class teacher as the key informant who knew the student's condition with certainty. The data collection techniques of this research were interviews, questionnaires, and documentation.

Qualitative data analysis activities are carried out when data collection takes place, namely data collection, after the data is collected from the field the next steps are data reduction, data display, and a conclusion drawing or verification (Soegiyono, 2015: 246).

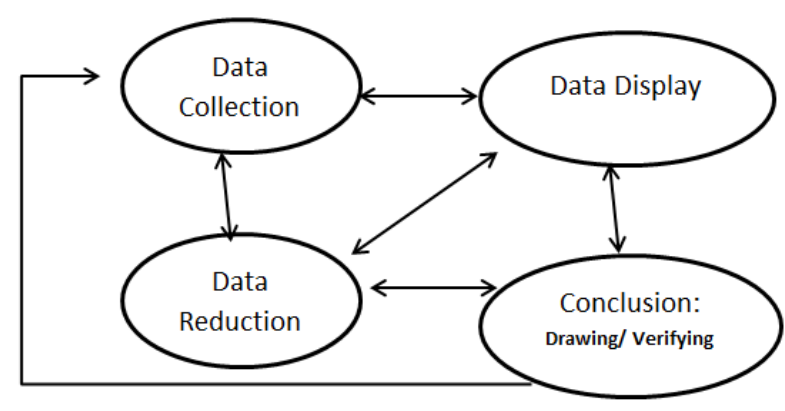

Gambar 1. Kompenen dalam analisis data (interactive model).

In this step, research activities are focused on collecting field data. While collecting data in the field, a lot of data will be obtained. The longer the researcher goes to the field, the more data will be, complex and complicated, therefore at the next stage the data reduction stage will be carried out. At this stage the research activity is to summarize, choose main things, focus on important things, look for themes and patterns based on data obtained from the field such as how to teach teachers to explain material, teacher attention to students who have difficulty learning material, teachers' efforts to improve students' understanding of English learning, analyze students' motivation to participate in English learning. After collecting and reducing data, the next step is to present the data. Presentation of data is done to make it easier to understand what is happening in the field and is presented in descriptive form, namely the results of observations obtained from the field about student learning difficulties in understanding the material in English lessons and the things that cause these difficulties.

The data analyzed in this research is in the form of descriptive, namely the results of data collection through the analyzed instruments and presented in descriptive form. All analysis results are presented in descriptive form, the analysis is carried out by understanding the symptoms found during the observation and linking them to the relevant theory so that the symptoms and cases under study can be understood. The data credibility test or the trustworthiness of the qualitative research results is carried out in several ways, such as: extension of observations, increasing persistence in research, triangulation, discussions with peers, negative case analysis, and memberchecks.

\section{Result and Discussion}

This research was conducted at SD Negeri 4 Pendem, which is a public elementary school having its address at Jalan Cendrawasih No. 15, Pendem Village, Negara District, Jembrana Regency. This research 
was conducted with the help of the participation of all fifth-grade students and fifth grade teachers of SD Negeri 4 Pendem.

Table 1. List of Research Resources

\begin{tabular}{lll}
\hline \multicolumn{1}{c}{ Name } & \multicolumn{1}{c}{ Position } & \multicolumn{1}{c}{ Obtained Data } \\
\hline $\begin{array}{l}\text { Fifth grade } \\
\text { teacher }\end{array}$ & $\begin{array}{l}\text { Fifth grade } \\
\text { teacher }\end{array}$ & $\begin{array}{l}\text { Opinions about the factors that influence the difficulty of learning } \\
\text { English experienced by students while participating in English } \\
\text { learning and the efforts made to overcome these learning } \\
\text { difficulties. }\end{array}$ \\
$\begin{array}{l}\text { Fifth-grade } \\
\text { student }\end{array}$ & $\begin{array}{l}\text { Fifth-grade } \\
\text { student }\end{array}$ & $\begin{array}{l}\text { Opinions about the factors that influence the difficulty of learning } \\
\text { English experienced by students while participating in English } \\
\text { learning and the efforts made to overcome these learning } \\
\text { difficulties. Obtaining data from the results of filling out the 22 } \\
\text { students' questionnaire }\end{array}$ \\
\hline
\end{tabular}

To see student learning difficulties, researchers used interviews with students, and the results of these interviews were: (1) There were 12 students who did not like English lessons, and 10 people who were happy with English lessons, (2) All students always came before the lesson. started, so as not to miss the material provided by the teacher, (3) Grade V SD Negeri 4 Pendem students, not all of them did their own assignments or homework, there were 12 students who made their own assignments, and there were 7 students who were helped by others, and there were 3 students who worked in groups by friends, (4) As many as 10 students said sometimes, and there were 5 students who said only during English lessons, and there were 7 students who said 20 to 30 minutes of learning time in English lessons, (4) A total of 16 students who have difficulty understanding in English lessons and 6 students who stated that English lessons are easy to understand, (5) A total of 12 students who understood when the teacher explained laskam and 10 students who were not clear when the teacher taught in English, (6) As many as 6 students understood when the teacher delivered the material and 16 students did not understand when the teacher delivered it, (7) As many as 18 students did not have printed books / package and 4 students who have printed books / packages. (8) all students said the facilities and infrastructure at the school were still good. (9) There were 16 students who said teachers did not use media during the learning process, and as many as 6 students said teachers sometimes use media during the learning process.

From the results of the questionnaire collected on the aspect of internal factors, it shows that one of the internal factors that causes difficulties in learning English in class V SD Negeri 4 Pendem is the presentation of English lessons that are less pleasing to students, students are still not motivated to follow the English learning process and interest students in learning English are still lacking. Based on the results of this questionnaire, students still have difficulty learning English. From the results of the questionnaire collected on the aspect of external factors, it shows that students have difficulty learning to learn English lessons caused by the process of implementing English learning that is conveyed by the teacher is not suitable for students, the teacher rarely uses teaching aids when learning is taking place and other factors are still lacking. encouragement of parents towards their children in learning.

From the results of the description above, it provides an understanding that there are many factors that can cause students to experience learning difficulties. The author classifies these factors into two factors, namely, internal and external factors. Internal factors are factors that come from within the students themselves, such as interests, talents, and motivation. while external factors are factors that come from outside the student or come from the environment. Students have learning difficulties. When viewed from doing their own assignments or homework, it is known that not all of SD Negeri 4 Pendem students do their own assignments or homework, there are 12 students who make their own assignments, and there are 7 students who are assisted by older siblings, and there are 3 students who do groups by friends. Then if it is seen from the students' understanding of the English material, it is known that there are 6 students who understand when the teacher delivers the material and there are 16 students who do not understand when the teacher delivers it. This is evident that almost all students being taught do not understand the material being taught. This happens because it is caused by several factors including insufficient learning of concepts, the lack of time allocation provided, the methods used are less varied and not innovative so that it is boring and does not attract students' interest, incomplete learning facilities and the lack of willingness to memorize or want to. study the material being taught.

Based on the results of research on internal factors that cause difficulty learning English in class $\mathrm{V}$ SD Negeri 4 Pendem is the presentation of English lessons that are less pleasing to students, students are still not motivated to participate in the English learning process and student interest in learning English 
both in at home or at school is still lacking. Research conducted by (Nida, dkk, 2020; Wulandari, dkk, 2020) stated that the learning process that is not innovative will make students bored and lose interest in learning.

Learning difficulties experienced by students are caused by various factors which state that the causes of learning difficulties can be grouped into two, namely internal factors and external factors (Izaak et al., 2016; Khaeroni \& Nopriyani, n.d.). Factors that come from within students (internal factors) include: intellectual abilities, affection such as feelings and self-confidence, motivation, maturity to learn, age, gender, study habits, memory skills, and sensory abilities such as seeing, listening, and feeling. While factors that come from outside students (external factors) include factors related to the learning process which includes teachers, learning quality, learning instruments or facilities in the form of hardware and software as well as the environment, both social and natural environments (Nani \& Evinna, 2019). These internal factors come from students, such as student IQ, student attitudes in learning, learning motivation, body health, and sensory abilities.

The IQ level of each student is different, some have fast cognitive development and some are slow. Based on the results of the analysis, it can be seen that, in class $V$ there are students who are smart and there are also students who are not smart, students who are smart when explained by the teacher will quickly grasp the material but on the other hand, students with low IQ will be slow in capturing the material. (Slameto, 2010; Susanto, 2013) argued that intelligence has a big influence on one's learning progress, in the same situation students who have a high level of intelligence will be more successful in learning than students who have a low level of intelligence. learning attitude is the tendency of students to do or not do learning activities. A positive attitude towards a subject is a good start for the learning process (Aswar, 2014). Conversely, a negative attitude towards subjects will have the potential to cause learning difficulties or make learning outcomes less than optimal. The results of the analysis show that students' attitudes towards English lessons vary, some like and some don't like English lessons. Students who do not like English lessons have negative attitudes towards learning English so that students do not follow learning well. (Mulyanah, Ishak, \& Iqbal, 2018; Sayd \& Nazarudin, 2018) argues that English is the field of study that students think is the most difficult, both according to students who do not experience learning difficulties and moreover according to students who have learning difficulties.

Motivation to learn serves to direct students' actions in learning (Emda, 2017; Farid, 2014). Apart from motivation by teachers, the role of parents in providing support for learning is very important. The results of the analysis show that the students' learning motivation is still low. Students also do not learn back material that has been taught at school when at home and students do not learn mathematics when there are no tests. The low motivation of students also results in students not being enthusiastic about learning English, causing difficulties in learning English. Research conducted by Ahmadi, Abu, \& Supriyono (2013) also stated that students with weak motivation appear indifferent, easily give up and their attention is not focused on the lesson as a result experience many learning difficulties.

These external factors are caused by factors from outside the students, including variations in teachers in teaching, use of learning media, school infrastructure, and family environment (Huda, 2013; Susanto, 2013). The methods used by teachers in teaching are less varied, teachers only use conventional methods. At the beginning of learning the teacher uses the lecture method to open the lesson, then the teacher explains the fraction material then the student representatives are asked to come forward to answer the questions given by the teacher. In the learning that is carried out, there are some students who feel bored with learning mathematics. This is also confirmed by research conducted by (Ningsih \& Dkk, 2018; Puspitasari, Sutarno, \& Dasna, 2016) which states that the conventional learning model makes students quickly bored in learning. The use of the right method will make it easier for students to understand the material and reduce the level of student boredom in the classroom (Putra, Margunayasa, \& Wibawa, 2017; Setyawan, Suniasih, \& Negara, 2017). Slameto (2010) states that the teaching methods used by the teacher are not good enough to affect student learning.

The use of learning media is very helpful for explaining the material (Arsyad, 2019; Putri \& Desyandari, 2019). It is important to present concrete learning media in learning English. Based on the results of observations and interviews with teachers and students, it was suggested that the teacher did not use concrete learning media in learning English so that students did not understand well the concepts being taught which resulted in students having difficulty understanding the concepts. The teacher only uses chalk to write on the blackboard. Facilities and infrastructure in schools do not support the learning process of English. Classrooms have windows and ventilation as air in and out so that the classroom is not stuffy, but the classroom does not have a fan, so it makes students less comfortable in the classroom because of the heat. During the observation, the researcher did not find a classroom that uses an LCD that can help the teacher to deliver the material more interestingly. Another condition that is less supportive for learning English is the layout of the field that can be seen directly from the class which results in 
students being less concentrated when another class is taking sports lessons in the field. Such unfavorable learning situations can allow learning to be stunted (Ahmadi et al., 2013; Anika \& Fajar, 2020).

The family is the first center of education for students. Guidance from parents and attention from parents is an important factor in student learning success (Tresnati, 2016; Vivi Novita Sari \& Sudirman, 2018). From the results of the analysis, it was found that students who indicated that they had difficulty learning English did not always get the attention of their parents at home. The economic condition of the family is one of the reasons parents pay less attention to students. Most of the students' parents work as laborers so they rarely accompany students to study at home, parents go to work in the morning and take their children to school and come home when it is evening so that when they are home parents feel tired and cause parents to be less supportive of learning activities students at home and student learning activities are borne by the school only. This is in accordance with the narrative (Ahmadi et al., 2013) that children who do not get supervision or guidance from parents are likely to have a lot of learning difficulties.

After finding the difficulties experienced by students and the factors that cause student difficulties, then we will discuss efforts to overcome difficulties in learning English. The analysis of efforts to overcome the difficulties of learning English in grade V at SD Negeri 4 Pendem was carried out by analyzing the results of the interviews conducted on the research subjects. The efforts to solve problems are (1) Using innovative learning media, using innovative learning media is very important in learning English because students cannot think abstractly, students think in terms of what is seen or concrete objects, (2) Increase language training English, teachers need to provide more practice to students who have difficulty learning English because with more practice students will increasingly understand and speak English fluently. How to provide more exercise does not have to be done in class, exercises can be given as homework to further monitor the development of student abilities, (3) Collaborating with parents, parents have an important role in providing motivation for students. Students who are given good attention at home will have good motivation to learn at school (Adiyani \& Susilaningsih, 2018; Nasution, 2019). For that parents need to always pay attention to the development of students' English learning. An example of a form of parent's attention to their child is that children are accompanied when they are studying at home because if the child is having difficulties in learning the parents can teach their children until the child understands the problem being worked on, the child is given additional learning hours at home in the form of tutoring Internal factor problems include: student characteristics, attitudes towards learning, learning concentration, the ability to process learning materials, the ability to explore learning outcomes, self-confidence, and study habits. While external factors include: teacher factors, social environment, school curriculum, and infrastructure.

\section{Conclusion}

Based on the results of the research, it shows that the difficulty of students in understanding English material is triggered by several things, especially in the less than optimal ability of teachers to present learning by not mastering learning materials, not using appropriate methods and media, and less able to manage class and the unavailability of handbook or textbooks for students.

\section{References}

Adiyani, \& Susilaningsih. (2018). Hubungan Lingkugan Keluarga Dan Gaya Belajar Dengan Hasil Belajar PKn Siswa Kelas V. Joyful Learning Journal, 7(3). Retrieved from http://journal.unnes.ac.id/sju/index.php/jlj

Ahmadi, Abu, \& Supriyono, W. (2013). Psikologi Belajar. Jakarta: Rineka Cipta.

Anika, \& Fajar. (2020). Efektivitas Model Pembelajaran Kooperatif Tipe Make-A Match Dalam Meningkatkan Kompetensi Sikap Siswa dan Kompetensi Pengetahuan Siswa Pada Pelajaran IPS. Jurnal Ilmiah Sekolah Dasar, 80-85. https://doi.org/http://dx.doi.org/10.23887/jisd.v4i1.24047

Arsyad, A. (2019). Media Pembelajaran. Jakarta: PT. Raja Grafindo Persada.

Astuti. (2017). Penerapan Pembelajaran Bilingual di TK Inklusi. Jurnal Pendidikan Anak, 3.

Aswar, C. (2014). Pencapaian Hasil Belajar Melalui Penumbuhan Sikap Mahasiswa. Latanida Journal, 2(2). https://doi.org/http://dx.doi.org/10.22373/lj.v2i2.1408

Basri, H. (2018). Strategi Belajar Kosakata Bahasa Inggris (English Vocabulary). Strategi Belajar Kosakata 

Bahasa
Inggris
(English
Vocabulary,
11(2),
432-444.

https://doi.org/http://dx.doi.org/10.19105/nuansa.v11i2.540

Brown, \& Douglas. (2000). Principles of Language Learning and Teaching. New Jersey: Prentice Hall Regents.

Emda, A. (2017). Kedudukan Motivasi Belajar Siswa dalam Pembelajaran. Lantanida Journal, 5(2). Retrieved from https://jurnal.ar-raniry.ac.id/index.php/lantanida/article/view/2838/2064

Farid, M. M. (2014). Pengaruh Motivasi Belajar, Gaya Belajar, Dan Lingkungan Belajar Pada Hasil Belajar Ekonomi Di SMA Negeri 1 Wringinanom Gresik. Jurnal Ekonomi Pendidikan Dan Kewirausahaan, 2(2), 142-156. https://doi.org/http://dx.doi.org/10.26740/jepk.v2n2.p142-156

Farnika, Ikhsan, \& Sofyan. (2015). Peningkatan Kemampuan Pemahaman Dan Pemecahan Masalah Matematis Sekolah Menengah Atas Dengan Model Pembelajaran Kooperatif Tipe Team Assisted Individualization. Jurnal Elemen Program Studi Matematika, 1(2), 144-152. Retrieved from http://ejournal.hamzanwadi.ac.id/index.php/jel/article/view/146

Huda, M. (2013). Model-model Pengajaran dan Pembelajaran. Yogyakarta: Pustaka Belajar.

Izaak, Esomar, \& Sopacua. (2016). Analisis Kesulitan Belajar Dan Pencapaian Hasil Belajar Siswa Melalui $\begin{array}{lllll}\text { Strategi Pembelajaran Inkuiri. Cakrawala } & \text { Pendidikan, }\end{array}$ https://doi.org/https://doi.org/10.21831/cp.v35i3.10706

Khaeroni, \& Nopriyani. (n.d.). Analisis Kesulitan Belajar Siswa Kelas V SD/MI Pada Pokok Bahasan Sistem Koordinat. 2018, 5(1), 76-93. https://doi.org/https://doi.org/10.24252/auladuna.v5i1a7.2018

Kurniawati, D. (2019). Keefektifan Pengajaran Kosakata Bahasa Inggris Pada Anak Sekolah Dasar Dengan Menggunakan Flash Card. Jurnal Pendidikan Dan Pembelajaran Dasar, 2(2), 59. https://doi.org/10.37484/manajemen_pelayanan_hotel.v2i2.40

Lubis, A. (2018). Integrasi Tik Dalam Pengajaran Bahasa Inggris Di Indonesia Abad Ke-21: Mitos Dan Realita. Cakrawala Pendidikan, 37(1), 11-24. Retrieved from https://journal.uny.ac.id/index.php/cp/article/view/16738/pdf

Makmun, A. S. (2001). Psikologi kependidikan. Bandung: Remaja Rosdakarya.

Mansyur, U. (2016). Inovasi Pembelajaran Bahasa Indonesia. Retorika, 9(2). https://doi.org/https://doi.org/10.26858/retorika.v9i2.3806

Miranti, E. F. I. (2015). Penggunaan Media Lagu Anak-Anak dalam Mengembangkan Kemampuan Kosakata Bahasa Inggris Siswa di PAUD. Jurnal Ilmiah Kependidikan, 2, 176. Retrieved from http://journal.lppmunindra.ac.id/index.php/Faktor/article/download/382/364

Miskawati, M. (2019). Upaya Meningkatkan Kreativitas Anak Dalam Pembelajaran Seni Tari Melalui Strategi Belajar Sambil Bermain di TK Islam Sa'adatul Khidmah Tahun Pelajaran 2016/2017. Jurnal Ilmiah Dikdaya, 9(1), 45. https://doi.org/10.33087/dikdaya.v9i1.123

Mulyanah, Ishak, \& Iqbal. (2018). Penerapan Metode Total Physical Response (TPR) dalam Penguasaan Kosakata Bahasa Inggris Sekolah Dasar (SD). Jurnal Pendidikan Sekolah Dasar, 4(2). https://doi.org/http://dx.doi.org/10.30870/jpsd.v4i2.3855

Nani, \& Evinna. (2019). Analisis Kesulitan Belajar Siswa Pada Pembelajaran Bahasa Indonesia Di Kelas V SDN 12 Singkawang. Journal of Educational Review And Research, 2(1). https://doi.org/https://dx.doi.org/10.26737/jerr.v2i1.1853

Nasution, S. (2019). Pendidikan Lingkungan Keluarga. Tazkiya, 8(1), 115-124.

Nida, \& Dkk. (2020). Pengembangan Media Kartu Bergambar Berorientasi Pendidikan Karakter Pada Mata Pelajaran Bahasa Bali. Jurnal EDUTECH Universitas Pendidikan Ganesha., 8(1), 16-31. Retrieved from https://ejournal.undiksha.ac.id/index.php/JEU/article/view/25393/15846

Ningsih, \& Dkk. (2018). Penerapan Problem Based Learning Untuk Meningkatkan Kemampuan Berpikir Kritis Dan Hasil Belajar Siswa Kelas III. Jurnal Pendidikan, 3(12), 1587-1593.

Puspitasari, R. P., Sutarno, \& Dasna, I. W. (2016). Pengaruh Model Problem Based Learning terhadap Kemampuan Berpikir Tingkat Tinggi dan Hasil Belajar Siswa Kelas V SD. Jurnal Penelitian Pendidikan Guru Sekolah Dasar, 4(2), 75-85. 
Putra, Margunayasa, \& Wibawa. (2017). Pengaruh Model Pembelajaran Inkuiri Terbimbing Berbantuan Peta Pikiran terhadap Hasil Belajar IPA Kelas V SD. MIMBAR PGSD Undiksha, 5(2), 1-10.

Putri, E. N. D., \& Desyandari. (2019). Penggunaan Media Lagu Dalam Pembelajaran Tematik di Sekolah Dasar. Jurnal Ilmu Pendidikan, 1(3), 233-236. https://doi.org/https://doi.org/10.31004/edukatif.v1i3.52

Ratminingsih, N. M. (2017). Metode dan Strategi Pembelajaran Bahasa Inggris. Depok: RajaGrafindo Persada.

Sayd, \& Nazarudin. (2018). Implementasi Metode Total Physical Response (TPR) Dalam Pembelajaran Bahasa Inggris Bagi Anak-Anak Sekolah Dasar Inpres Liliba Kupang. Jurnal Bisnis Dan Manajemen, 3. Retrieved from http://www.jurnal.pnk.ac.id/index.php/bisman/article/view/244/152

Setyawan, I. W. P. A., Suniasih, N. W., \& Negara, I. G. A. O. (2017). Pengaruh Quantum Teaching Berbasis Catur Kelas V Sd Gugus Srikandi Denpasar Timur 2016 / 2017. MIMBAR PGSD Undiksha, 2(5). https://doi.org/http://dx.doi.org/10.23887/jjpgsd.v5i2.10762

Slameto. (2010). Belajar dan Faktor-Faktor Yang Mempengaruhinya. Jakarta: Rineka Cipta.

Sugihartono. (2007). Model Pembelajaran Inovatif serta Penerapannya pada SD/SMP CI-BI. Semarang: Rajawali Pers.

Sujana, I. W. C. (2019). Fungsi Dan Tujuan Pendidikan Indonesia. Adi Widya: Jurnal Pendidikan Dasar, 4(1), 29. https://doi.org/10.25078/aw.v4i1.927

Suryana, S. (2017). Permasalahan Mutu Pendidikan Dalam Perspektif Pembangunan Pendidikan. Jurnal Edukasi, 2(1). Retrieved https://journal.unnes.ac.id/nju/index.php/edukasi/article/view/971.

Susanto, A. (2013). Teori Belajar dan Pembelajaran di Sekolah Dasar. Jakarta: Kencana Prenada Media Group.

Tresnati, K. N. (2016). Hubungan lingkungan keluarga dan minat belajar terhadap hasil belajar IPS siswa kelas IV SD di gugus kresna dan shinta kecamatan semarang barat. Universitas Negeri Malang.

Uno, H. B. (2007). Profesi Kependidikan. Jakarta: Bumi Aksara.

Vivi Novita Sari, A., \& Sudirman, D. (2018). Hubungan Lingkungan Keluarga dan Motivasi dengan Hasil Belajar Kelas IV SD. Jurnal Pedagogi, 1-12. Retrieved from http://jurnal.fkip.unila.ac.id/index.php/pgsd/article/view/18022

Wahyudi, A., \& Indri. (2017). Strategi Pemecahan Masalah Matematika. Salatiga: Satya Wacana University Press.

Widodo, H. (2015). Potret Pendidikan Di Indonesia Dan Kesiapannya Dalam Menghadapi Masyarakat Ekonomi Asia (MEA) Heri Widodo. Cendikia: Jurnal Kependidikan Dan Kemasyarakatan, 13(2), 293237. https://doi.org/https://doi.org/10.21154/cendekia.v13i2.250.

Wirasasmita, \& Hendriawan. (2020). Analisis Efisiensi Kinerja Pendidik terhadap Hasil Pembelajaran Pendidikan Jasmani pada Siswa Sekolah. Mimbar Pendidikan, 5(1), 75-90. https://doi.org/https://doi.org/10.17509/mimbardik.v5i1.24152

Wulandari, \& Dkk. (2020). Pengembangan Pembelajaran Blended Pada Mata Kuliah Ahara Yoga Semester II di IHDN Denpasar. Jurnal Edutech Undiksha, 8(1), 1-15. https://doi.org/http://dx.doi.org/10.23887/jeu.v8i1.26459 